\title{
EFFICIENCY MEASUREMENT OF REGULATION SYSTEMS OF CHOSEN EU COUNTRIES: EFFECTS OF BANKING UNION IMPLEMENTATION
}

\author{
[Měření efektivity regulatorních systémů ve vybraných zemích EU: dopad \\ zavedení bankovní unie]
}

\author{
Martin Hodula ${ }^{1}$ \\ ${ }^{I}$ Vysoká škola báňská - Technická univerzita Ostrava, Ekonomická fakulta, katedra Evropské integrace, \\ Sokolská trída 33,70121 Ostrava \\ Email:martin.hodula@vsb.cz
}

\begin{abstract}
This article investigates the efficiency and potential effects of establishing European banking union. We build on recapitalizing banks model introduced by Freixas (2003) and Schoenmaker and Siegmann (2013) to capture the efficiency improvement of resolution over banks in distress. Our data contains Europe's Top 27 banks by their level of equity. Mathematical evidence suggests efficiency improvement of resolution mechanism in all of analyzed economies in referenced years $(2005,2007,2009$ and 2012). The results also confirmed initial hypothesis that the positive effects of moving from home to supranational regulation framework are much more significant in years of good economic performance.
\end{abstract}

Keywords: banking regulation and supervision, banking union, efficiency, European Union.

JEL classification: G01, G18, G28

Doručeno redakci: 23.2.2014; Recenzováno: 13.5.2014; 19.5.2014; Schváleno k publikování: 11.2.2015

\section{Úvod}

Rozhodnutí představitelů Evropské unie (EU) o zavedení bankovní unie, ve které bankovní regulace a dohled, stejně jako garance nad depozity a správa problémových bank, bude integrována např́ič eurozónou (EA) s možností pro státy stojící mimo EA - tzv. „outs“ se účastnit, mělo za úkol zajistit budoucí stabilitu evropského bankovního systému. Toto pokrizové opatření bylo jednou z mnoha odpovědí na finanční krizi z roku 2008, která se následně přelila do dalších sektorů hospodářství, aby poté vyvrcholila $\mathrm{v}$ dluhovou krizi eurozóny. Oznámení projektu bankovní unie (EBU), zvýšení limitů pro pojištění depozit, posílení kapitálové vybavenosti záchranných mechanismů ESFS (Evropský nástroj finanční stability) a EFSM (Evropský mechanismus finanční stabilizace), přijetí směrnice CRD IV a nařízení CRR a konečně pak spuštění ESM (Evropský stabilizační mechanismus) v lednu 2013 jsou pouze pomyslnou špičkou ledovce, ale jasně ukazují směr, kterým se EA a potažmo celá EU rozhodla jít. Je zde patrná snaha vytvořit záchrannou sít' nad celou eurozónou. Otázkou však je, zda skutečné problémy neleží vně této sítě nebo zda není tato sít' špatně zkonstruovaná. Je jasné, že pouze oznámit záměr přechodu $\mathrm{k}$ bankovní unie $\mathrm{v}$ rámci eurozóny je mnohem snažsí než samotná implementace. Vzhledem k tomu, že evropské banky poskytují více než tři čtvrtiny všech úvěrů v rámci EU, mnoho ekonomů se obává, že regulace takto rozvinutého bankovního systému nebude pouze technická otázka, ale že bude třeba učinit také mnoho subjektivních rozhodnutí, které mohou následně celou implementaci ohrozit (možná rizika implementace bankovní unie představují ve svých studiích např. Admati a Hellwig, 2013; Haldane, 2012). Evropské vlády jsou samozřejmě zdrženlivé v otázce převodu svých pravomocí a do jisté míry také kontroly nad více než třemi trilióny bankovních aktiv na nadnárodní úroveň. Zde proto také vyvstává důležitá otázka, zda rozhodnutí participace v EBU je spíše tržní či politické rozhodnutí. 
Lze tedy říci, že od dob vytvoření samotné eurozóny se v případě evropské bankovní unie jedná o nejvýznamnější počin v rámci evropské měnové politiky. Tento článek si klade za cíl pomocí modelu popisující rekapitalizaci bank (Freixas, 2003; Schoenmaker a Siegmann, 2013) analyzovat efektivitu rezolučních mechanismů a potencionální efekty zavedení evropské bankovní unie. Měření bylo provedeno na vzorku 27 největších evropských bank co do výše jejich aktiv v letech 2005, 2007, 2009 a 2012. Výsledné hodnoty zlepšení efektivity rekapitalizace se ukázaly jako výrazně vyšší v době ekonomického růstu, kdy banky vykazují tendence k rozšiřování svých zahraničních vazeb (průměrné zlepšení efektivity za všechny banky bylo $69 \%$ pro rok 2007 a $62 \%$ v roce 2009). Průměrné hodnoty pro vybrané země ukazují u všech vysoké procento zlepšení efektivity při nutnosti rekapitalizace. Toto se týká, jak členských zemí eurozóny (Německo, Francie, Španělsko, Irsko, Belgie, Itálie a Nizozemí), tak nečlenských zemí jako jsou Velká Británie a Švédsko.

Tento článek má následující strukturu. První kapitola představuje základní literaturu popisující efekty zavedení bankovní unie v rámci EA, potažmo EU a v kostce popisuje stav implementace EBU do roku 2013. V rámci druhé kapitoly je představen použitý model rekapitalizace bank. Nejprve jsou nastaveny základní podmínky modelu, poté jsou odvozeny porovnávací měřítka změny efektivity $\mathrm{v}$ rámci různých systémů bankovní regulace a dohledu (národní vs. nadnárodní systém). Třetí kapitola poskytuje empirické výsledky modelu pro 27 největších evropských bank. Závěr článku je uveden ve čtvrté kapitole.

\section{Přehled související literatury}

Často diskutovaná, v souvislosti s nedávnou finanční krizí, je existence tzv. trilematu finančního dohledu, který vychází z pojetí paradoxu neslučitelné trojice (impossible trinity). Podobně jako se již několikrát v praxi ověřilo, že nelze dosahovat současně kurzové stability, volného pohybu kapitálu a nezávislé měnové politiky, finanční krize ukázala, že nelze mít zároveň stabilní finanční systém (1), integrované finanční trhy (2) a finanční dohled na národním základě (3), (do detailů rozebírá problém trilematu finančního dohledu ve své práci Schoenmaker, 2011b). Claessens a kol. (2010) uvádí jako prríklad existence trilematu kolaps Lehman Brothers a situaci kolem pojišt'ovací společnosti AIG v USA a průběh rekapitalizace banky Fortis v zemích Beneluxu mezi lety 2007-2009. V př́padě AIG jednala vláda USA zdánlivě jednotně a rychle. AIG si dlouhodobě udržovala silné pozice a vysokou aktivitu na trhu s vládními CDS. Vláda USA tedy odsouhlasila jednotně pomoct AIG a poskytla záruky, které pomohly společnosti vyhnout se nutnosti rekapitalizace (bylo dosaženo jednoty cílů 1 a 3). Naopak v př́ípadě investiční banky Lehman Brothers, která měla silnou pozici kromě USA hlavně v Anglii, byl však zcela opuštěn cíl 2. Dalším prŕíkladem, tentokrát z Evropy, je pokus o záchranu banky Fortis, která byla aktivní především ve státech Benelexu, kde také držela většinovou část svých aktiv. Podmínky zde byly takřka ideální pro organizovanou rekapitalizaci a dosažení všech tří cílů. Díky chybějící legislativě a komplikované struktuře byla však nakonec Fortis rekapitalizována zvlášt' a pouze po částech, které spadaly do kompetencí národních regulátorů. Obecné fungování trilematu v podmínkách mezinárodního obchodu popisuje ve své práci např. Rodrik (2000).

Existuje velké množství autorů, kteří se snaží vyřešit trilema finančního dohledu. Lze stanovit třri hlavní proudy literatury $\mathrm{v}$ závislosti na navrhovaném způsobu řešení. V rámci prvního proudu navrhuje řešení ve své studii Rogoff (1999). Ten argumentuje, že státní intervence do finančního systému pouze navyšují morální hazard a pro zajištění stability by tedy měly být co nejvíce omezeny. Přestože argument morálního hazardu má své opodstatnění, v minulosti bylo již několikrát dokázáno, že právě dobře provedené státní zásahy mohou finanční krizi vyřšsit rychle a efektivně (myšleno s co nejnižšími náklady), více v pracích 
Claessens a kol. (2010) nebo Laeven a Valencia (2012). Druhý proud v sobě slučuje autory, kteří razí myšlenku segmentace národních trhů pomocí restrikcí toků v rámci mezinárodního obchodu (Eichengreen, 1999). V př́padě mezinárodních bank, segmentace má být dosaženo vytvořením sítě zcela nezávislých dceřiných společností. Třetí proud navrhuje pravý opak, a sice nadnárodní systém regulace a dohledu. Obsfeld (2009) a Fisher (1999) např́klad navrhují vytvoření institutu mezinárodního věřitele poslední instance. Eatwell a Taylor (2000) pak rozpracovali myšlenku tvorby jednoho mezinárodního regulátora.

Tento článek společně s mnoha dalšími (Schoenmaker a Siegmann, 2013; Elliott, 2012; Beck a kol., 2011) spadá do třetího proudu literatury. Př́nos článku je v analýze přímých efektů zavedení bankovní unie $\mathrm{v}$ rámci EU a dokázání hypotézy, že ony př́nosy budou vždy výraznější v dobách ekonomického růstu než v období recese.

EU v současné době dokončuje projekt bankovní unie k posílení finanční stability. Dluhová krize eurozóny jasně ukázala, že finanční stabilita již nadále nemůže být zajištěna efektivně na národní úrovně (too-big-to-fail hypotéza). Stále vyšší počet ekonomů také poukazuje na fakt, že skutečným problémem světové ekonomiky (potažmo EU) zůstává masivní zadluženost soukromého a veřejného sektoru (Liu a Rosenberg, 2013; Hudson, 2012; Soto, 2009). Zmiňována je také škodlivá vazba mezi zadluženými vládami na jedné straně a stabilitou bank na straně druhé. Tato d’ábelská smyčka je také zmíněna ve studii Brunnermeier a kol. (2011), kde zmiňuje důvod, proč zůstává fiskální pozice evropských ekonomik slabá. Na vině je právě ona vazba, kdy evropské banky drží na svých účtech podstatnou část veřejného (i soukromého) dluhu. Tato vzájemná závislost byla matematicky dokázána ve studii Altera a Schülera (2012). Ti za použití denních CDS vybraných zemí eurozóny dokázali vztah mezi úrovní úvěrového rizika a zadlužeností vlád v době krize.

Je tedy integrovaná bankovní unie ideálním řešením tohoto problému? Dle studie Elliotta (2012) k tomu má blízko. Elliott popisuje základní prvky evropské bankovní unie a stav její implementace. Argumentuje také, že právě extrémní propojenost evropského bankovního systému je základní stavebním kamenem úspěšného fungování EBU.

\section{Model popisující rekapitalizaci bank}

Model, použitý k měření přírůstku efektivity nového rámce koordinace regulatorních systémů v rámci bankovní unie je postaven na modelu Freixase (2003) a Schoenmakera a Siegmanna (2013). Uvažujme rozhodnutí ex-post, jestli rekapitalizovat nebo likvidovat banku, která se ocitla ve finanční nouzi. Rozhodnutí, zda zachránit (rekapitalizovat) či zavřít banku, je poté proměnná $x$, která nabývá hodnot $\{0,1\}$. V modelu pak $B$ představuje společenský př́nos rekapitalizace a $C$ její náklady. Společenský přínos lze chápat, mimo jiné, jako faktické zlepšení finanční stability systému a snížení rizika nákazy (Acharya, 2009). Náklady pak představují šiřrení rizika nákazy, narušení stability systému, riziko zadření úvěrů. Schoenmaker (2013) k tomuto uvádí jako př́íklad kolaps americké investiční banky Lehman Brothers, který způsobil rozšiřrení nákazy. Schoenmaker argumentuje, že v tomto př́padě náklady (domácí i přeshraniční) mohly být minimalizovány rozhodnutím zachránit nebo rekapitalizovat banku, tedy $\mathrm{v}$ tomto př́padě platilo $B>C$. Pokud by ovšem banka byla vyhodnocena jako systémově nevýznamná, pak $B<C$ a rekapitalizace není na místě. Dalším zjednodušením modelu je pak předpoklad, že existují pouze dvě možnosti, jak řešit situaci, kdy je banka $v$ problémech.

Př́nosy rekapitalizace lze také chápat jako př́nosy zachování finanční stability dosažené provedením úspěšného bail-outu. Pro názornost: uvažujme stav, kdy celkové př́nosy 
rekapitalizace pro přeshraničně aktivní banku (konkrétně ve dvou zemích A a B) jsou 50 miliónů. Těchto 50 miliónů bude tedy rozděleno mezi zemi A a zemi $\mathrm{B}$. Tyto př́nosy pak budou zcela totožné s těmi, které by dosahovala pouze banka aktivní v jedné, tj. domovské, zemi. Model tedy nebere $\mathrm{v}$ úvahu možnost, že banka může být aktivní také mimo oblast uzavřené bankovní unie. Tato geografická segmentace aktiv banky by daný celkový přínos rekapitalizace samozřejmě snížila, protože část př́nosů by unikla do třetí země (tzv. free-rider problém). Př́nosy rekapitalizace lze také chápat jako předcházení dočasně snížené dostupnosti úvěrů (zadření úvěrů) kvůli zhoršení bilance bank (k tomuto může docházet $\mathrm{z}$ různých důvodů). Proto je v následujícím modelu využita geografická segmentace bankovních aktiv jakožto zjednodušující znázornění přínosů rekapitalizace. Toto zjednodušení je v souladu s poznatky, které zveřejnil ve svém článku Bernanke (1983). Brei, Gambacorta a Von Peter (2013) zase našli důkaz toho, že banky, především během krize, často používají dodatečný kapitál k většímu poskytování úvěrů. Toto se děje často ve chvíli, kdy jejich úroveň kapitálu přesáhne požadovanou úroveň. Jinak řečeno, př́ípadná rekapitalizace by se následně promítla stejným způsobem do úvěrového kanálu ekonomiky ve chvíli, kdy by banka vyhodnotila svou situaci jako stabilní. Proto je náš předpoklad postaven na faktu, že v př́ipadě rekapitalizace bude regulátor zajišt'ovat kapitál banky v celé jeho původní výši (aby př́edešel zadření úvěrů).

Současný systém regulace a dohledu lze nazvat „národni““, tj. př́pad, kdy o rekapitalizaci rozhoduje pouze domovská země banky. Tato pak bere v potaz pouze fakt, jestli př́nosy rekapitalizace pro domácí zemi převýší její náklady. Podmínku pro bail-out pak píšeme:

$$
\alpha_{\text {home }} . B>C
$$

kde $\alpha_{\text {home }}$ značí prínos rekapitalizace pouze pro domovskou zemi. Uvažujme pro názornost mezinárodně propojenou banku s významným podílem přeshraničních aktiv, tedy mimo domácí zemi. V př́ípadě problémů banky by poté aplikace „národního“ řešení rekapitalizace byla neefektivní, protože veškeré náklady rekapitalizace by nesla pouze domácí země, zatímco př́nos by byl mezinárodně sdílen. Taková situace byla pozorována např́klad ve Velké Británii při rekapitalizaci RBS nebo v Německu u Commerzbank. Obě tyto banky byly a stále jsou enormně mezinárodně propojeny a tedy výhody bail-outu byly sdíleny. Náklady ovšem nesly pouze domácí země. Efektivnější se jeví užití řešení „nadnárodního“, kdy:

$$
\sum_{i}^{n} \alpha_{i} \cdot B>C
$$

kde $\alpha_{i}$ je prŕnos z provedeného bail-outu zemi $i$, suma od $i$ do $n$ zemí znázorn̆uje skupinu zemí, které spadají pod jurisdikci nadnárodního regulátora. V následující části budou země, které se účastní bankovní unie označovány jako EBU a země neúčastnící se OUTS. Celkový podíl přínosů rekapitalizace je roven 1 . Píšeme:

$$
\alpha_{\text {home }}+\alpha_{E B U}+\alpha_{\text {OUTS }}=1
$$

Nadnárodní autorita bude tedy maximalizovat př́nosy pod podmínkou:

$$
x= \begin{cases}1 & \text { if } \alpha_{E B U} . B \geq C \\ 0 & \text { if } \alpha_{E B U} . B<C\end{cases}
$$

Dle rovnice (4) by „nadnárodní“ řešení mohlo být efektivnější (ve smyslu zajištění sdílených nákladů na rekapitalizaci) v situaci, kdy přeshraniční propojení banky je signifikantní a figuruje hlavně uvnitř EU. Nadnárodní řešení má tedy potenciál ke zvýšení př́nosů rekapitalizace a zajištění účinného a efektivního bail-outu. Problémem naopak může být pro 
mezinárodně propojené banky s větším množstvím aktiv mimo prostor EU: $\alpha_{E B U} \ll 1$. $\mathrm{V}$ tomto prŕpadě by pak určitý podíl př́nosů rekapitalizace byl „ztracen“ ve prospěch zemí mimo EU, zatímco náklady by sdílely pouze státy EU mezi sebou (prostřednictvím nadnárodního regulátora).

V Obrázku 1 je znázorněno nejefektivnější řešení, kdy se přeshraničně sdílené přínosy rovnají nákladům. Př́́mka je pak charakterizována jako rovnost $B=C$, při sklonu 1 . V př́ípadě, že se nacházíme pod touto referenční linií, pak jsou celkové př́nosy menší než celkové náklady a tedy bail-out není výhodný. Př́imka značená EBU_res znázorňuje nadnárodní řešení bailoutu (rovnice 2) a vzdálenost od nejefektivnějšího řešení se píše jako $\alpha_{E B U}$. $B>C$. Tento zápis upravíme do podoby $B=C / \alpha_{E B U}$ a poté $1 / \alpha_{E B U}$. HOME_res znamená řešení národní a po úpravě rovnice vzdálenosti dostáváme $1 / \alpha_{\text {HOME }}$. Jak vidíme, tato př́mka se nachází nad EBU_res a plocha mezi nimi znázorňuje zlepšení při přechodu ze systému národního na nadnárodního regulátora. Tento přechod ale není nutný v př́ípadě, že daný bankovní systém je spíše uzavřený a banky tedy drží minimum přshraničních aktiv. Následuje analýza vybraných bank v rámci EU.

Obrázek 1: Grafické zobrazení měření efektivity

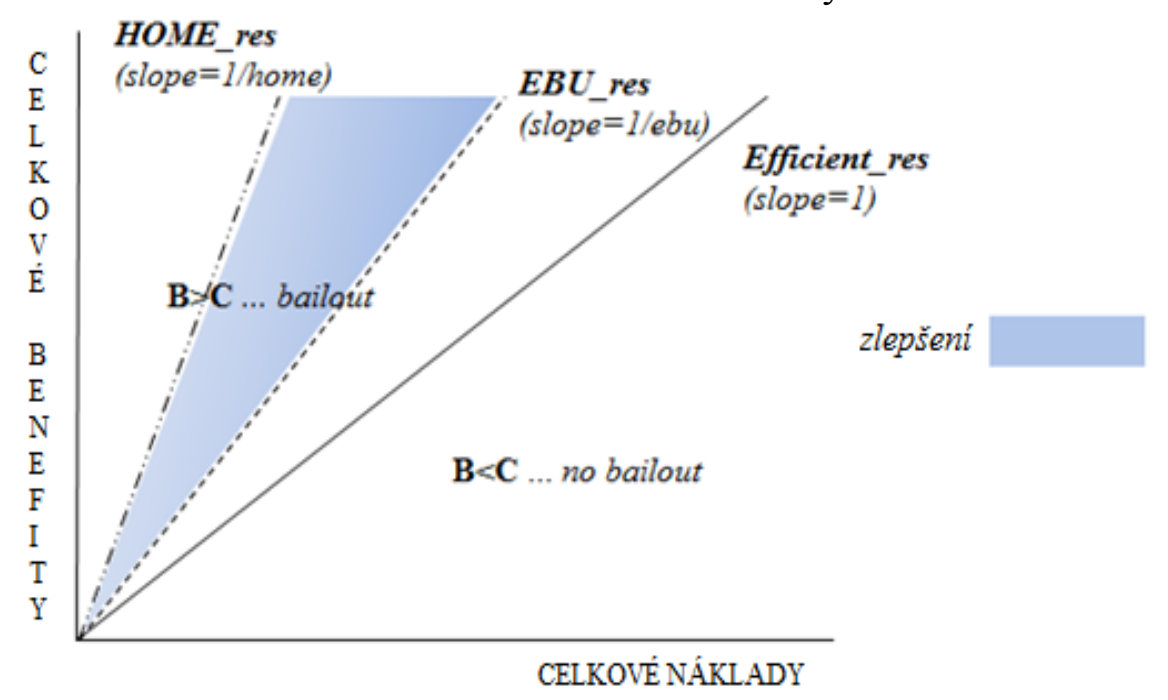

Zdroj: Schoenmaker a Siegmann (2013), str. 6.

\section{Nastavení modelu}

Protože cílem článku je hodnocení efektivity rekapitalice při přechodu ze systému národního na nadnárodního regulátora, následuje jednoduchá analýza efektivity. Základní jednotkou, která byla použita k charakteristice velikosti bank, je výše bankovních aktiv. Smyslem analýzy je ukázat potencionální zlepšení systému regulace při nutnosti bail-outu po zapojení do bankovní unie (zlepšení je zde myšleno z pohledu rozdělení nákladů). Možnost pádu kterékoliv z vybraných bank je nezbytným předpokladem modelu.

Ukazatel efektivity lze v situaci, kdy je banka $j$ rekapitalizování (zachráněna), psát jako:

$$
B_{j} \geq C_{j}
$$

Rovnice (5) je zobrazena také v Obrázku 1, jako referenční 45 stupňová linie se sklonem 1. Jestliže tedy $\beta$ bude parametr znázorňující přínosy, pak celkové př́inosy rekapitalizace banky $j$ jsou $B_{j}=\beta . E_{j}$, kde $E_{j}$ je kapitál banky (viz výše Brei, Gambacorta a Von Peter, 2013). Minimální hodnota parametru $\beta$, kdy bude výhodné $\mathrm{z}$ pohledu regulátora přsstoupit k rekapitalizaci, píšeme jako: 


$$
\frac{B_{j}}{C_{j}}=\frac{\beta \cdot E_{j}}{E_{j}}=\beta \geq 1
$$

Po úpravě vyjde $B \geq C$, a tedy ukazatel efektivity pro zahájení rekapitalizace je $\beta=1$. Jestliže vycházíme z původní rovnice (1), pak pro řešení národní bude banka $j \mathrm{v}$ domácím státě $h$ zachráněna, jestliže:

$$
\alpha_{j, h} \cdot B_{j} \geq C_{j}
$$

Poté, co rovnici (7) upravíme, dostáváme $B_{j} \geq \frac{1}{\alpha_{j, h}}$. $C_{j}$ a z rovnice (6) pak již lze odvodit hraniční hodnotu rekapitalizace pro systém národního regulátora jako $\beta_{\text {home }}=1 / \alpha_{h}$. Za použití stejného postupu pak získáme měřítko také pro nadnárodní řešení $\beta_{E B U}=1 / \alpha_{E B U}$ a píšeme:

$$
\sum_{i}^{n} \alpha_{j, h} \cdot B_{j} \geq C_{j}
$$

Jak již bylo uvedeno, cílem článku je změřit efektivity rekapitalizace př̀i přechodu ze systému národního na nadnárodního regulátora. Jestliže jsme si již výše definovali základní ukazatel efektivity jako $\beta=1$, pak od této hodnoty musíme odvozovat efektivitu různých systémů regulace. Vzdálenost národního systému regulace od ideálního řešení $\beta=1$ pak lze definovat jako rozdíl mezi její hraniční hodnotou a ukazatelem efektivity:

$$
D_{j}^{\text {home }}=\frac{1}{\alpha_{h}}-1
$$

Tento index bude nabývat hodnot od 0 do 1 . 0 pro čistě domácí banky bez jakýchkoli zahraničních aktiv (protože $\alpha_{h}$ by byl roven 1). Index se naopak bude blížit 1 pro velké mezinárodní banky. Opět stejným postupem odvodíme vzdálenost od ideálního řešení pro systém nadnárodního regulátora:

$$
D_{j}^{E B U}=\frac{1}{\alpha_{E B U}}-1
$$

Opět bude tento index nabývat hodnot od 0 do 1 . Tento index by se blížil 0 u bank, které mají velkou část svých aktiv navázány v zemích mimo potencionální bankovní unii (OUTS). Na závěr je nutné vypočítat celkové zlepšení efektivity, když se budeme pohybovat ve směru od národního k nadnárodnímu systému (v Obrázku 1 je to plocha mezi křivkami HOME_res a EBU_res). Píšeme:

$$
I M P_{i, j}=\frac{D_{j}^{\text {home }}-D_{j}^{E B U}}{D_{j}^{\text {home }}}
$$

Indikátor IMP bude nabývat hodnot od 0 do $100 \%$. Nulovou hodnotu bychom mohli pozorovat u bank s nulovými přeshraničními aktivy $\left(D_{j}^{E B U}=0\right)$. Protože analýza si klade za cíl vyhodnotit zlepšení efektivity pro danou zemi jako celek, musíme vytvořit sumu zlepšení jednotlivých bank $j \mathrm{v}$ dané zemi $i$, píšeme:

$$
I M P_{i}=\sum_{j} I M P_{i, j}
$$




\section{Vstupní data}

Analýza zahrnuje čtyři rozličná časová období pro možnost komparace výsledků. Nejprve je hodnoceno zlepšení efektivity rezolučních mechanismů pro rok 2005, poté 2007 jakožto vrchol konjunktury, dále 2009 jako krizový rok a nakonec pro rok 2012, tedy pro po-krizové období. Toto rozdělení by mělo odpovědět na otázku, zda se hodnoty zlepšení efektivity regulace budou lišit $\mathrm{v}$ dobách $\mathrm{s}$ odlišnou ekonomickou výkoností. Zde testujeme předpoklad, že $\mathrm{v}$ dobách konjunktury budou banky rozšiřovat své přeshraniční zájmy, zatímco $\mathrm{v}$ recesi budou více soustředěni na situaci na domácím trhu. Zdrojovou databází je The Banker (2012), Zprávy o struktuře evropského bankovnictví a především pak jednotlivé výroční zprávy bank ze kterých byla získána struktura bankovních aktiv. Vzorek obsahuje 27 největších evropských bank dle výše aktiv, které obhospodařují celkově více než polovinu celkových bankovních aktiv v rámci EU. Jsou také odpovědné za více než tři čtvrtiny přeshraničních aktiv mimo EU. Banky jsou z těchto zemí EU: Velká Británie (5), Francie (5), Německo (4), Španělsko (4), Nizozemí (3), Itálie (2), Belgie (2), Švédsko (1) a Irsko (1). Č́́sla v závorce představují počet bank ve vzorku. Malé a středně velké banky nejsou brány v úvahu, nebot' se u nich dá předpokládat větší orientace na domácí klientelu.

\section{Výsledky pro jednotlivé banky a země}

Pro každou banku ze vzorku 27 největších evropských bank dle výše aktiv byla vypočítána jejich vzdálenost mezi řešením národním a nadnárodním. Struktura bankovních aktiv pro 27 největších bank v rámci EU v letech 2005, 2007, 2009 a 2012 je zobrazena v Př́loze 1. Změny mezi jednotlivými obdobími nejsou výrazné, v průměru za sledované banky se podíl na domácím trhu pohyboval kolem $58 \%$ v roce 2005 a $60 \%$ v roce 2012 . Významnější změny nejsou pozorovány ani $u$ aktiv směřující přes hranice $v$ rámci Evropy ( $22 \%$ a $21 \%)$ a pak u aktiv pro zbytek světa $(21 \%$ a $19 \%)$. Velmi zajímavá je změna pro zbytek světa mezi roky $2007(19 \%)$ a 2009 (21\%), tedy roky s naprosto odlišnou ekonomickou výkonností a vnímáním rizika. Zde hodnoty aktiv narostly v období recese a je patrný přesun aktiv do třetích zemí. Naznačuje to také možnou hypotézu, že zlepšení při přechodu z národního na národního regulátora by mělo být výraznější v období konjunktury, kdy banky mají sklony spíše své přeshraniční zájmy rozšiřovat, zatímco v období recese je prvotním zájmem stabilizace mateřské společnosti. Obrázek 2 ukazuje hodnoty segmentace aktiv pro 27 největších evropských bank. Hodnoty jsou vypočítány za rok 2012 na základě dat zveřejněných ve výročních zprávách.

Obrázek 2: Segmentace aktiv 27 největších bank EU, dle výše celkových aktiv, 2012

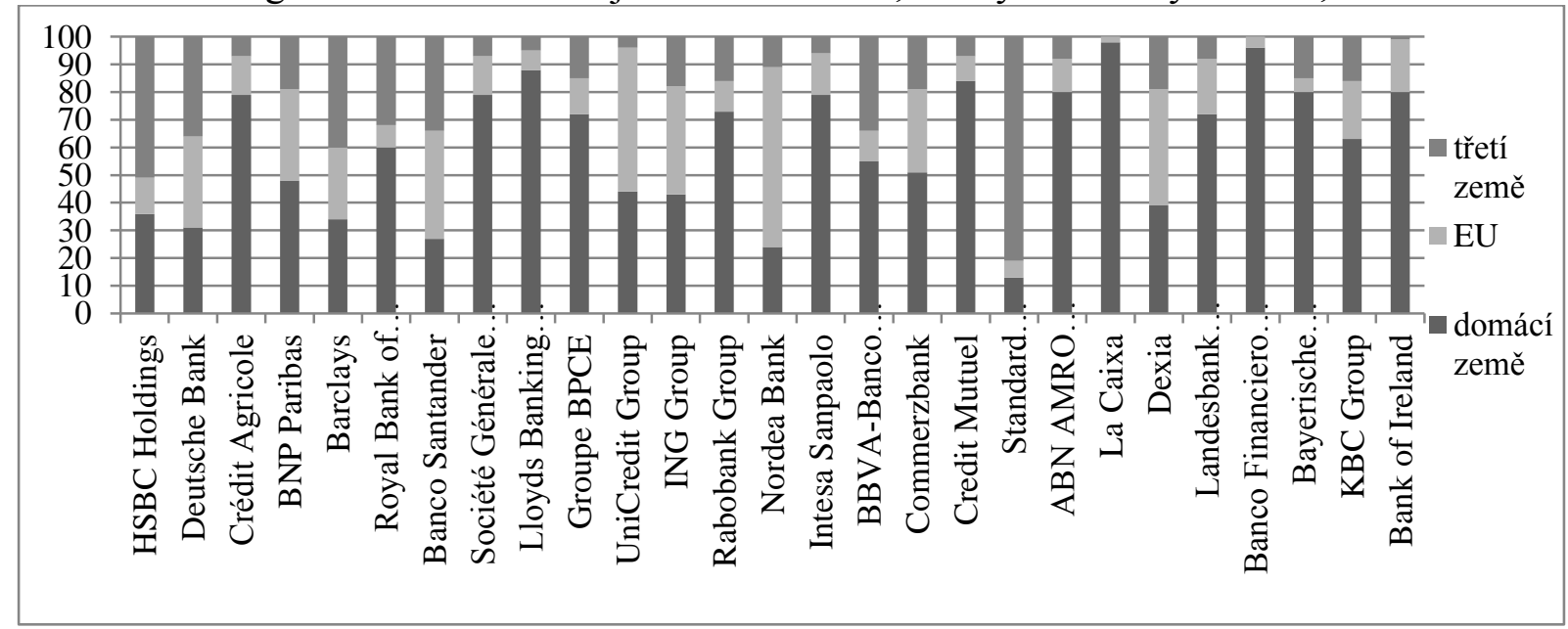

Zdroj: výroční zprávy daných bank za rok 2012, vlastní zpracování 
Geografická segmentace aktiv je brána jako proxy pro geografické rozdělení prŕnosů. Z obrázku výše je patrné, že nejvíce přeshraničně orientované jsou britské banky HSBC, Barclays a Standard Chartered s více než polovinou bankovních aktiv mimo domácí zemi. Část aktiv však směřuje do zámoří, čímž budou efekty potencionálního vstoupení do EBU sníženy (již zmiňovaný free-rider problém). Naopak např. Nordea má většinu svých aktiv v zemích EU, stejně jako UniCredit. U těchto budou efekty zapojení do EBU velmi vysoké.

Z údajů, uvedených ve Zprávě o struktuře evropského bankovnictví z listopadu 2012, vyplývá, že nejvíce přeshraničně orientovaný je bankovní systém Belgie, poté Irska a Velké Británie. Lze předpokládat, že zlepšení efektivity bude právě u těchto zemí nejvýraznější. U Velké Británie je nicméně důležitý také podíl aktiv v rámci třetích zemí, který by mohl efekty zlepšení snižovat. Naopak čistě evropsky orientované jsou bankovní systémy Španělska a Itálie. Následují výsledky měření efektivity pro jednotlivé státy (Obrázek 3). Protože nás hlavně zajímá zlepšení efektivity rezolučních mechanismů, pro každou banku $j$ v našem vzorku 27 bank vypočítáme vzdálenost mezi národním a nadnárodním systémem regulace a dle rovnice (11) výsledky sumarizujeme do domácí země.

Lze argumentovat, že všechny státy mají př́inos z posílené stability bankovního sektoru v rámci bankovní unie. Ono zlepšení efektivity rekapitalizace je tedy placené kolektivně zeměmi, které budou v EBU participovat. Analýza je však zaměřena pouze na stranu výnosů. Náklady pro dané země by patrně představoval upsaný kapitálový klíč pro ESM (více o analýze nákladů a výnosů píše Hodula, 2014). Obrázek 3 a Př́loha 2 ukazují tedy výsledky měření efektivity rekapitalizace pro země EU. Protože pouze 9 zemí má své banky mezi Top 27 , výsledky je třeba interpretovat opatrně. Ukazuje to také na velkou koncentraci bankovního sektoru v rámci EU. Velké množství zemí, zejména ze střední a východní Evropy, jsou téměř kompletně závislé na zahraničních bankách.

Obrázek 3: Výsledky měření efektivity pro vybrané země EU, v \%

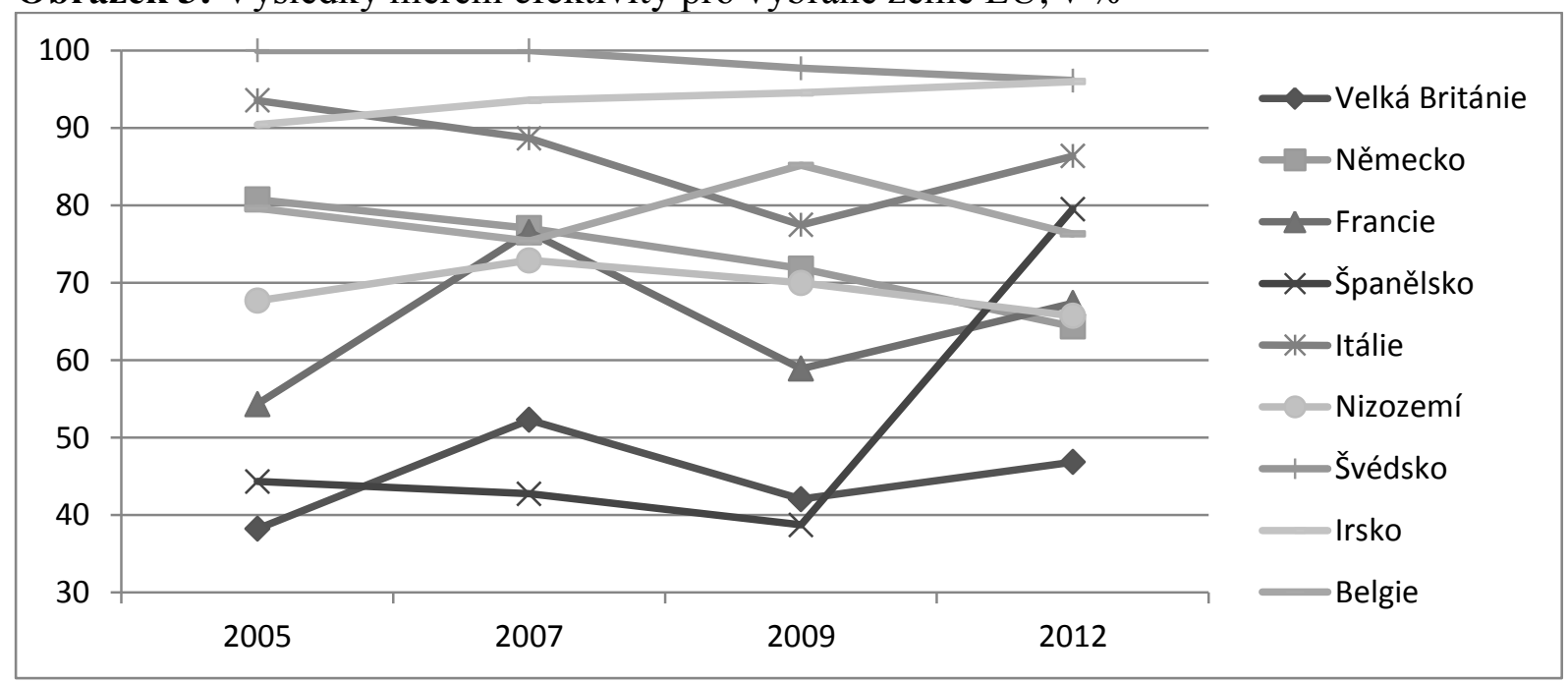

Zdroj: vlastní výpočty autora

Zlepšení efektivity rezolučního mechanismu pro každou zemi je chápáno jako snížení podílu na celkových nákladech rekapitalizace domovské banky. Domácí země bude platit pouze svou část, která má vycházet $\mathrm{z}$ upsaného kapitálu $\mathrm{v}$ rámci rezolučního mechanismu EBU. Nejvýraznější změny lze pozorovat mezi roky 2005 a 2007 a poté v mezidobí 2007-2009. Pro Velkou Británii je hodnota zlepšení efektivity nejmenší, což je způsobeno především jejím zaměřením nejen na evropský trh ale také na trhy mimo EU, což celkový efekt oslabuje. 
Potvrzuje se zde také hypotéza, že zlepšení efektivity je větší v časech ekonomického růstu. U Německa hodnota IMP mezi sledovanými roky klesá, je však stále velmi vysoká na úrovni $64 \%$ v roce 2012. Německo a její bankovní systém je však zvláštní př́pad. Za posledních 10 let do roku 2008 německá ekonomika rostla v průměru o $6 \%$ za rok. To znamená, že německé banky musely nahromadit velké množství zahraničních aktiv, přičemž část těchto investic se již odepsaly v rámci záchrany Řecka, kde se celkové ztráty na bankovních aktivech odhadují ve výši $24 \%$. Důvodem pro pokles hodnoty IMP je pak zvýšená orientace, především u německých Landesbank, na bankovní trhy mimo EU. Francie nejvýrazněji ukazuje, jak moc ekonomická situace ovlivňuje orientaci bankovního sektoru. Hodnoty IMP se zde výrazně odlišují mezi jednotlivými lety $-54 \%$ v roce $2005,77 \%$ na vrcholu období konjunktury $\mathrm{v}$ roce 2007, propad hodnoty po začátku krize v roce 2009 na $59 \%$ a konečně pak nejaktuálnější hodnota 67 \%. Největší španělské banky vykazovaly dlouhodobě výraznou orientaci na domácí sektor. Největší Banca Santander (ES) však postupem let začala expandovat i na evropský trh (nejvýrazněji se změnila segmentace aktiv mezi lety 2009 a 2012). Itálie je, podobně jako Španělsko, spíše evropsky orientovaná, co se týče bankovního sektoru. I tady tak můžeme pozorovat vysoké zlepšení efektivity při přechodu na nadnárodní systém bankovní regulace. Nizozemí, Švédsko, Irsko a Belgie jsou ve vzorku zastoupeny malým počtem bank a výsledky je tedy nutno interpretovat s rozvahou.

Výsledky modelu naznačují, že v případě přechodu ze systému národního na nadnárodního regulátora, by došlo ve všech sledovaných ekonomikách ke zlepšení efektivity rezolučních mechanismů (rekapitalizace). Toto platí nejen pro členské země eurozóny ve vzorku (Německo, Francie, Španělsko, Itálie, Nizozemí, Irsko a Belgie), ale také pro nečlenské země Velkou Británii a Švédsko. Bylo také dokázáno, že pozitivní efekty zapojení do bankovní unie jsou vyšší v časech konjunktury, kdy banky vykazují tendence rozšiřovat své přeshraniční zájmy. Je také nutné zmínit nečlenské země eurozóny, jejichž bankovní systémy patří k nejotevřenějším v EU - konkrétně se jedná o Českou republiku, Estonsko, Mad'arsko, Lotyšsko a Rumunsko. Můžeme argumentovat, že v případě, že banky v těchto zemích jsou z 90 \% a více vlastněny zahraničními subjekty v rámci EU, i zde existuje silné odůvodnění ke vstupu a participaci na EBU. A to i v případě, že tyto státy neplánují v nejbližší době přijetí společné měny. Výhody pro tyto státy jsou především ve stabilitě mateřských společností jejich bank. Závislost mezi životaschopností dceřiné banky na zdraví mateřské byla matematicky prokázána např. ve studii Bruno a Schin (2012) nebo Jeon a kol (2013).

\section{Závěr}

Po začátku finanční krize v roce 2008 bylo očividné, že finanční sektor není dostatečně regulovaný a pravidla Basel II nejsou dostatečná. Morální hazard společně se sílící vazbou mezi veřejným a soukromým zadlužením a bankami daly základ myšlence Evropské bankovní unie, tedy společnému systému bankovní regulace a dohledu. Článek měl za cíl pomocí modelu popisující rekapitalizaci bank analyzovat efektivitu a potencionální efekty zavedení evropské bankovní unie. Měření bylo provedeno na vzorku 27 největších evropských bank co do výše jejich aktiv v letech 2005, 2007, 2009 a 2012. Výsledné hodnoty zlepšení efektivity rekapitalizace se ukázaly jako výrazně vyšší v době ekonomického růstu, kdy banky vykazují tendence k rozšiřování svých zahraničních vazeb (průměrné zlepšení efektivity za všechny banky bylo $69 \%$ pro rok 2007 a $62 \%$ v roce 2009). Průměrné hodnoty pro vybrané země ukazují u všech vysoké procento zlepšení efektivity při nutnosti rekapitalizace. Toto se týká, jak členských zemí eurozóny (Německo, Francie, Španělsko, Irsko, Belgie, Itálie a Nizozemí), tak nečlenských zemí jako jsou Velká Británie a Švédsko. 
Co se týče dalších nečlenských zemí eurozóny, zejména pak zemí centrální a východní Evropy, i u těchto se dají předpokládat pozitivní efekty vyplývající z participace na bankovní unii. Díky značné otevřenosti těchto bankovních systémů, výhody pro tyto státy jsou především ve stabilitě mateřských společností jejich bank.

\section{Poděkování}

Tento článek vznikl za podpory projektu OP VK „Výzkumný tým pro modelování ekonomických a finančních procesů na VŠB-TU Ostrava“ - číslo projektu CZ.1.07/2.3.00/20.0296. Děkuji také účastníkům International Conference on Finance and Banking (Ostrava, 2013) a International Conference on European Integration (Ostrava, 2014) za užitečné komentáře a doporučení. Děkuji také za komentáře anonymních recenzentů.

\section{Literatura}

[1] ADMATI, A. a M. HELLWIG, 2013. The Bankers' New Clothes: What's Wrong with Banking and What to Do about It. Princeton: Princeton University Press. ISBN 978-1400846-56-6.

[2] ACHARYA, V., 2009. A theory of systemic risk and design of prudential bank regulation. Journal of Financial Stability, 5, 224-255. ISSN 1572-3089.

[3] ALTER, A. a Y. SCHÜLER, 2012. Credit Spread Interdependencies of European States and Banks During the Financial Crisis. Journal of Banking and Finance, 36(12), 34443468. ISSN 0378-4266.

[4] BECK, T., R. TODOROV a W. WAGNER, 2013. Supervising cross-border banks: theory, evidence and policy. Economic Policy, 28, 5-44. ISSN 1468-0327.

[5] BERNANKE, B. S., 1983. Nonmonetary effects of the financial crisis in the propagation of the great depression. American Economic Review, 73, 257-276. ISSN 0002-8282.

[6] BREI, M., L. GAMBACORTA a G. VON PETER, 2013. Rescue packages and bank lending. Journal of Banking \& Finance, 37(2), 490-505. ISSN 0378-4266.

[7] BRUNNERMEIER, M., L. GARICANO, P. LANE, S. NIEUWERBURGH, M. PAGANO, R. REIS, T. SANTOS a D. VAYANOS, 2011. European Safe Bonds: An executive summary [online]. [vid. 7. 6. 2014]. Dostupné $\mathrm{z}$ www: http://scholar.princeton.edu/markus/files/06h_esbies_exec_summary.pdf

[8] BRUNO, V. a H. SHIN, 2012. Capital Flows, Cross-Border Banking and Global Liquidity. NBER Working Paper Series, 19038. Cambridge: NBER. ISSN 0898-2937.

[9] CLAESSENS, S., R. HERRING a D. SCHOENMAKER, 2010. A Safer World Financial System: Improving the Resolution of Systemic Institutions. 12th Geneva Report on the World Economy. London: CEPR. ISBN 978-1-907142-09-3.

[10] EATWELL, J. a L. TAYLOR, 2000. Global Finance at Risk: The Case for International Regulation. Cambridge: Polity Press. ISBN 978-0-7456-2510-2.

[11] ECB, 2013. Banking Structures Report: November 2013 [online]. [vid. 7. 6. 2014]. Dostupné z www: http://www.ecb.europa.eu/pub/pdf/other/bankingstructuresreport 201311en.pdf

[12] EICHENGREEN, B., 1999. Towards A New International Financial Architecture: A Practical Post-Asia Agenda. Washington, DC: Institute for International Economics. ISBN 978-0-88132-270-5.

[13] ELLIOTT, D. J., 2012. Key Issues on European Banking Union. Global Economy and Development Working Paper, 52. ISSN 1939-9383. 
[14] FISHER, S., 1999. On the need for an international lender of last resort. Journal of Economic Perspectives, 13, 85-104. ISSN 0895-3309.

[15] FREIXAS, X., 2003. Crisis Management in Europe. In: J. KREMERS, D. SCHOENMAKER and P. WIERTS, eds. Financial Supervision in Europe. Cheltenham: Edward Elgar, s. 102-119. ISBN 978-18-40649-31-4.

[16] HALDANE, A. G., 2012. The Dog and the Frisbee. Bank of England Speech [online]. [vid. 7. 6. 2014]. Dostupné z http://www.bankofengland.co.uk/publications/ Documents/speeches/2012/speech596.pdf

[17] HODULA, M., 2014. On the Mechanics of European Banks Bailout under Banking Union Conditions: cost-benefit analysis. In: I. HONOVÁ, ed. Proceedings of the 2nd International Conference on European Integration. Ostrava: VSB - Technical University of Ostrava, s. 244-252. ISBN 978-80-248-3388-0.

[18] HUDSON, M., 2012. The Bubble and Beyond. New York: ISLET. ISBN 978-39-8148420-5.

[19] JEON, B., M. OLIVERO a J. WU, 2013. Multinational Banking and the International Transmission of Financial Shocks: Evidence from foreign bank subsidiaries. Journal of Banking and Finance, 37(2), 952-972. ISSN 0378-4266.

[20] LAEVEN, L. a F. VALENCIA, 2012. Systemic Banking Crises Database: An Update. IMF Working Paper [online]. No. WP/12/163. [vid. 7. 6. 2014]. Dostupné $\mathrm{z}$ https://www.imf.org/external/pubs/ft/wp/2012/wp12163.pdf

[21] LIU, Y. a CH. B. ROSENBERG, 2013. Dealing with Private Debt Distress in the Wake of the European Financial Crisis. IMF Working Paper, [online]. No. WP/13/44. [vid. 7. 6. 2014]. Dostupné z https://www.imf.org/external/pubs/ft/wp/2012/wp12163.pdf

[22] OBSTFELD, M., 2009. Lenders of Last Resort in a Globalized World. CEPR Discussion Paper [online]. No. DP7355. [vid. 7. 6. 2014]. Dostupné Z http://eml.berkeley.edu/ obstfeld/lendersoflastresort.pdf

[23] RODRIK, D., 2000. How far will international economic integration go? Journal of Economic Perspectives, 14, 177-186. ISSN 0895-3309.

[24] ROGOFF, K., 1999. International institutions for reducing global financial instability. Journal of Economic Perspectives, 13, 21-42. ISSN 0895-3309.

[25] SCHOENMAKER, D., 2011a. The European Banking Landscape after the Crisis. DSF Policy Paper Series [online]. No. 12. [vid. 7. 6. 2014]. Dostupné z http://papers.ssrn.com/sol3/papers.cfm?abstract_id=1824307

[26] SCHOENMAKER, D., 2011b. The Financial Trilemma. Economics Letters, 111(1), 5759. ISSN 0165-1765.

[27] SCHOENMAKER, D. a CH. VAN LAECKE, 2006. Current State of Cross-Border Banking. LSE Financial Markets Group Paper Series, 168. ISSN 1359-9151-168.

[28] SCHOENMAKER, D. a A. SIEGMANN, 2013. Efficiency Gains of a European Banking Union. Tinbergen Institute Discussion Paper [online]. No. 026. [vid. 7. 6. 2014]. Dostupné z http://papers.ssrn.com/sol3/papers.cfm?abstract_id=2214919

[29] SOTO, J. H., 2009. Money, Bank Credit, and Economic Cycles. Alabama: Ludwig von Mises Institute. ISBN 978-19-33550-39-8. 


\section{Př́lohy}

Příloha 1: Segmentace aktiv u 27 největších bank v rámci EU dle výše celkových aktiv (v \%)

\begin{tabular}{|c|c|c|c|c|c|c|c|c|c|c|c|c|c|}
\hline \multirow[b]{2}{*}{ Pořadí } & \multirow[b]{2}{*}{ Bank Name } & \multicolumn{3}{|c|}{2005} & \multicolumn{3}{|c|}{2007} & \multicolumn{3}{|c|}{2009} & \multicolumn{3}{|c|}{2012} \\
\hline & & $\mathbf{h}$ & $\mathbf{s}$ & $\mathbf{w}$ & h & $\mathbf{S}$ & $\mathbf{w}$ & $\mathbf{h}$ & $\mathbf{S}$ & $\mathbf{w}$ & $\mathbf{h}$ & $\mathbf{S}$ & $\mathbf{w}$ \\
\hline 1. & HSBC Holdings (EN) & 25 & 9 & 66 & 33 & 14 & 53 & 27 & 17 & 56 & 36 & 13 & 51 \\
\hline 2. & eutsche Bank (DE) & 28 & 36 & 36 & 28 & 28 & 44 & 30 & 33 & 37 & 31 & 33 & 36 \\
\hline 3. & rédit Agricole (FR) & 83 & 9 & 8 & 71 & 15 & 14 & 62 & 23 & 15 & 79 & 14 & 7 \\
\hline 4. & NP Paribas (FR) & 55 & 21 & 24 & 55 & 35 & 10 & 45 & 34 & 21 & 48 & 33 & 19 \\
\hline 5. & $\operatorname{arclays}(\mathrm{UK})$ & 50 & 16 & 34 & 36 & 22 & 42 & 39 & 16 & 45 & 34 & 26 & 40 \\
\hline 6. & oyal Bank of Scotland (UK) & 77 & 7 & 16 & 65 & 12 & 23 & 56 & 19 & 25 & 60 & 8 & 32 \\
\hline 7. & Banco Santander $(\mathrm{ES})$ & 40 & 26 & 34 & 33 & 50 & 17 & 31 & 30 & 39 & 27 & 39 & 34 \\
\hline 8. & ciété Générale Group (FR) & 57 & 21 & 22 & 81 & 13 & 6 & 56 & 27 & 17 & 79 & 14 & 7 \\
\hline 9. & Lloyds Banking Group (UK) & 90 & 5 & 5 & 88 & 11 & 1 & 92 & 4 & 4 & 88 & 7 & 5 \\
\hline 10. & roupe BPCE (FR) & 40 & 47 & 13 & 77 & 16 & 7 & 77 & 5 & 18 & 72 & 13 & 15 \\
\hline 11. & UniCredit Group (IT) & 24 & 72 & 4 & 52 & 44 & 4 & 41 & 24 & 35 & 44 & 52 & 4 \\
\hline 12. & NG Group (NL) & 23 & 29 & 48 & 44 & 40 & 16 & 43 & 37 & 20 & 43 & 39 & 18 \\
\hline 13. & abobank Group (NL) & 73 & 14 & 13 & 80 & 12 & 8 & 65 & 14 & 21 & 73 & 11 & 16 \\
\hline 14. & ordea Bank (s & 25 & 75 & 0 & 22 & 75 & 3 & 21 & 71 & 8 & 24 & 65 & 11 \\
\hline 15. & tesa Sannaolo & 92 & 7 & 1 & 85 & 11 & 4 & 79 & 19 & 2 & 79 & 15 & 6 \\
\hline 16. & $\mathrm{BVA}(\mathrm{ES})$ & 40 & 3 & 57 & 66 & 21 & 13 & 41 & 2 & 57 & 55 & 11 & 34 \\
\hline 17. & ommerzbank & 71 & 25 & 4 & 55 & 38 & 7 & 72 & 20 & 8 & 51 & 30 & 19 \\
\hline 18. & redit Mutuel ( & 100 & 0 & 0 & 81 & 15 & 4 & 93 & 3 & 4 & 84 & 9 & 7 \\
\hline 19. & Standard Chartered Group (UK) & 10 & 2 & 88 & 14 & 2 & 84 & 15 & 0 & 85 & 13 & 6 & 81 \\
\hline 20. & ABN AMRO Group NV (NL) & 34 & 30 & 36 & 55 & 37 & 8 & 84 & 12 & 4 & 80 & 12 & 8 \\
\hline 21. & La Caixa (ES) & 100 & 0 & 0 & 100 & 0 & 0 & 100 & 0 & 0 & 98 & 2 & 0 \\
\hline 22. & Dexia (BE) & 51 & 37 & 12 & 44 & 44 & 12 & 36 & 47 & 17 & 39 & 42 & 19 \\
\hline 23. & Landesbank B-W (DE) & 82 & 15 & 3 & 76 & 16 & 8 & 81 & 16 & 3 & 72 & 20 & 8 \\
\hline 24. & Financiero y de Ahorros SA (ES) & 98 & 2 & 0 & 95 & 5 & 0 & 96 & 3 & 1 & 96 & 4 & 0 \\
\hline 25. & Bayerische Landesbank (DE) & 78 & 14 & 8 & 84 & 11 & 5 & 84 & 7 & 9 & 80 & 5 & 15 \\
\hline 26. & KBC Group (BE) & 50 & 29 & 21 & 46 & 33 & 21 & 47 & 36 & 17 & 63 & 21 & 16 \\
\hline 27. & Bank of Ireland (IE) & 60 & 34 & 6 & 55 & 40 & 5 & 64 & 33 & 3 & 80 & 19 & \\
\hline
\end{tabular}

Poznámka: $h$ - podíl aktiv banky na domácím trhu, $s$ - podíl aktiv banky v rámci zemí EU, $w$ - podíl aktiv banky v rámci zbytku světa

Zdroj: Údaje za rok 2005 převzaty ze studie Schoenmaker a Van Laecke (2006), za rok 2007 a 2009 Schoenmaker (2011a). Údaje za rok 2012 jsou vlastní výpočty autora na základě výročních zpráv jednotlivých bank. 
Př́loha 2: Vypočtené hodnoty IMP pro 27 největších bank v rámci EU (v \%)

\begin{tabular}{|c|c|c|c|c|c|c|c|c|c|c|c|c|}
\hline \multirow[t]{2}{*}{ Název banky } & \multicolumn{3}{|l|}{2005} & \multicolumn{3}{|r|}{2007} & \multicolumn{3}{|r|}{2009} & \multicolumn{3}{|r|}{2012} \\
\hline & h & $\mathbf{S}$ & IMP & $\mathbf{h}$ & $\mathbf{S}$ & IMP & $\mathbf{h}$ & $\mathbf{s}$ & IMP & $\mathbf{h}$ & $\mathbf{s}$ & IMP \\
\hline HSBC Holdings (EN) & 3,00 & 1,94 & 35,29 & 3,17 & 1,70 & 46,23 & 2,70 & 1,27 & 52,93 & 1,78 & 1,04 & 41,45 \\
\hline Deutsche Bank (DE) & 2,57 & 0,56 & 78,13 & 2,23 & 0,64 & 71,28 & 2,33 & 0,59 & 74,83 & 2,23 & 0,56 & 74,73 \\
\hline Crédit Agricole (FR) & 0,20 & 0,09 & 57,54 & 0,67 & 0,16 & 75,58 & 0,61 & 0,18 & 71,21 & 0,27 & 0,08 & 71,68 \\
\hline BNP Paribas (FR) & 0,82 & 0,32 & 61,40 & 1,08 & 0,27 & 75,46 & 1,22 & 0,27 & 78,25 & 1,08 & 0,23 & 78,35 \\
\hline Barclays (UK) & 1,00 & 0,52 & 48,48 & 1,17 & 0,64 & 45,54 & 1,56 & 0,82 & 47,69 & 1,94 & 0,67 & 65,66 \\
\hline Royal Bank of Scotland (UK) & 0,30 & 0,19 & 36,23 & 0,85 & 0,39 & 54,35 & 0,79 & 0,33 & 57,58 & 0,67 & 0,47 & 29,41 \\
\hline Banco Santander (ES) & 1,50 & 0,52 & 65,66 & 1,56 & 0,52 & 67,06 & 2,23 & 0,64 & 71,28 & 2,70 & 0,52 & 80,95 \\
\hline Société Générale Group (FR) & 0,75 & 0,28 & 62,61 & 0,69 & 0,19 & 72,59 & 0,79 & 0,20 & 73,93 & 0,27 & 0,08 & 71,68 \\
\hline Lloyds Banking Group (UK) & 0,11 & 0,05 & 52,63 & 0,01 & 0,00 & 100,00 & 0,09 & 0,04 & 52,08 & 0,14 & 0,05 & 61,40 \\
\hline Groupe BPCE (FR) & 1,50 & 0,15 & 90,04 & 0,30 & 0,08 & 74,80 & 0,30 & 0,22 & 26,51 & 0,39 & 0,18 & 54,62 \\
\hline UniCredit Group (IT) & 3,17 & 0,04 & 98,68 & 1,50 & 0,02 & 98,64 & 1,44 & 0,54 & 62,58 & 1,27 & 0,04 & 96,73 \\
\hline ING Group (NL) & 3,35 & 0,92 & 72,43 & 2,33 & 0,79 & 66,33 & 1,33 & 0,25 & \begin{tabular}{|l|l|}
81,14 \\
82,0
\end{tabular} & 1,33 & 0,22 & 83,44 \\
\hline Rabobank Group (NL) & 0,37 & 0,15 & 59,60 & 0,33 & 0,12 & 62,92 & 0,54 & 0,27 & 50,63 & 0,37 & 0,19 & 48,50 \\
\hline Nordea Bank (SE) & 3,00 & 0,00 & 100,00 & 2,70 & 0,00 & 100,00 & 3,76 & 0,09 & 97,69 & 3,17 & 0,12 & 96,10 \\
\hline Intesa Sanpaolo (IT) & 0,09 & 0,01 & 88,38 & 0,30 & 0,06 & 78,63 & 0,27 & 0,02 & 92,32 & 0,27 & 0,06 & 75,99 \\
\hline BBVA (ES) & 1,50 & 1,33 & 11,63 & 0,89 & 0,85 & 3,94 & 1,44 & 1,33 & 7,88 & 0,82 & 0,52 & 37,04 \\
\hline Commerzbank (DE) & 0,41 & 0,04 & 89,80 & 0,32 & 0,04 & 86,81 & 0,39 & 0,09 & 77,64 & 0,96 & 0,23 & 75,59 \\
\hline Credit Mutuel (FR) & 0,00 & 0,00 & 0,00 & 0,06 & 0,01 & 84,18 & 0,08 & 0,04 & 44,64 & 0,19 & 0,08 & 60,48 \\
\hline Standard Chartered Group (UK) & 9,00 & 7,33 & 18,52 & 6,69 & 5,67 & 15,33 & 5,67 & 5,67 & 0,00 & 6,69 & 4,26 & 36,30 \\
\hline ABN AMRO Group NV (NL) & 1,94 & 0,56 & 71,02 & 0,82 & 0,09 & 89,37 & 0,19 & 0,04 & 78,13 & 0,25 & 0,09 & 65,22 \\
\hline La Caixa (ES) & 0,00 & 0,00 & 0,00 & 0,00 & 0,00 & 0,00 & 0,00 & 0,00 & 0,00 & 0,02 & 0,00 & 100,00 \\
\hline Dexia $(\mathrm{BE})$ & 0,96 & 0,14 & 85,81 & 1,00 & 0,27 & 73,42 & 1,78 & 0,20 & 88,48 & 1,56 & 0,23 & 85,00 \\
\hline Landesbank B-W (DE) & 0,22 & 0,03 & 85,91 & 0,12 & 0,01 & 91,83 & 0,23 & 0,03 & 86,81 & 0,39 & 0,09 & 77,64 \\
\hline Financiero y de Ahorros SA (ES) & 0,02 & 0,00 & 100,00 & 0,05 & 0,00 & 100,00 & 0,04 & 0,01 & 75,76 & 0,04 & 0,00 & 100,00 \\
\hline Bayerische Landesbank (DE) & 0,28 & 0,09 & 69,17 & 0,27 & 0,11 & 58,20 & 0,19 & 0,10 & 48,08 & 0,25 & 0,18 & 29,41 \\
\hline KBC Group (BE) & 1,00 & 0,27 & 73,42 & 1,17 & 0,27 & 77,36 & 1,13 & 0,20 & 81,84 & 0,59 & 0,19 & 67,57 \\
\hline Bank of Ireland (IE) & 0,67 & 0,06 & 90,43 & 0,82 & 0,05 & 93,57 & 0,56 & 0,03 & 94,50 & 0,25 & 0,01 & 95,96 \\
\hline
\end{tabular}

Zdroj: vlastní výpočty autora. 